\title{
Predictors of response to cardiac resynchronization therapy on pre-implantation cardiovascular magnetic resonance imaging
}

\author{
Usha Manian ${ }^{1 *}$, Raymond Yee ${ }^{1}$, Immaculate Nevis ${ }^{2}$, David McCarty ${ }^{1}$, John Stirrat ${ }^{2}$, David Scholl ${ }^{2}$, Lorne J Gula ${ }^{1}$, \\ Peter Leong-Sit ${ }^{1}$, Maria Drangova ${ }^{2,3}$, James A White ${ }^{1,2}$
}

From 16th Annual SCMR Scientific Sessions

San Francisco, CA, USA. 31 January - 3 February 2013

\section{Background}

Cardiac resynchronization therapy (CRT) is an established treatment for severe heart failure. However, up to $40 \%$ of patients do not respond. While regional scar distribution has received focused attention, the predictive utility of global markers of remodeling and irreversible injury has not been well explored.

\section{Methods}

Sixty-eight patients receiving CRT underwent pre-implant cardiovascular MRI followed by serial echocardiography at 3 and 6 months. Blinded measurement of Left Ventricular (LV) and Right Ventricular (RV) chamber dimensions, volumes and mass were performed from short axis cine datasets. LV dysynchrony was measured by septal to lateral wall delay. Total LV scar burden was determined from Late Gadolinium Enhancement (LGE) images using manual contour tracing of endocardial and epicardial borders with application of a signal threshold $\geq 5 \mathrm{SD}$ above reference myocardium. Response to CRT was defined as a reduction in LV end-systolic volume (ESV) $\geq 15 \%$ at 6 months.

\section{Results}

The mean age was $66.3 \pm 8.9$ years with a mean LV Ejection fraction (EF) of $25.2 \pm 7.2 \%$. Overall, 47 patients $(69 \%)$ responded. Among all baseline measures $\operatorname{LVEDV}(\mathrm{p}=0.03), \operatorname{LVESV}(\mathrm{p}=0.045), \operatorname{RV} \mathrm{EF}(\mathrm{p}=0.0349)$ and total scar burden $(\mathrm{p}=0.018)$ were the only significant predictors of CRT response. Multivariate analysis showed total scar burden to be the only independent predictor of CRT response ( $\mathrm{p}=0.015)$.

Medicine, London Health Sciences Centre, London, ON, Canada Full list of author information is available at the end of the article

\section{Conclusions}

Pre-implantation MRI offers markers for the prediction of response to CRT. Of these, total scar burden appears to be an independent predictor of response and may be of assistance in the selection of optimal candidates.

\section{Funding}

None

\section{Author details}

'Medicine, London Health Sciences Centre, London, ON, Canada. ${ }^{2}$ Imaging Research Laboratory, Robarts Research Institute, Western University, London, ON, Canada. ${ }^{3}$ Medical Biophysics, Western University, London, ON, Canada.

Published: 30 January 2013

\section{doi:10.1186/1532-429X-15-S1-E40}

Cite this article as: Manian et al:: Predictors of response to cardiac resynchronization therapy on pre-implantation cardiovascular magnetic resonance imaging. Journal of Cardiovascular Magnetic Resonance 201315 (Suppl 1):E40.

Submit your next manuscript to BioMed Central and take full advantage of:

- Convenient online submission

- Thorough peer review

- No space constraints or color figure charges

- Immediate publication on acceptance

- Inclusion in PubMed, CAS, Scopus and Google Scholar

- Research which is freely available for redistribution

\section{() Biomed Central}

(c) 2013 Manian et al; licensee BioMed Central Ltd. This is an Open Access article distributed under the terms of the Creative Commons Attribution License (http://creativecommons.org/licenses/by/2.0), which permits unrestricted use, distribution, and reproduction in any medium, provided the original work is properly cited. 